\title{
Legal and social aspects of the state participation in the governance of the large corporations in Russia
}

\author{
Oxana Cherkasova ${ }^{1, *}$, and Sergey Sosnovskikh ${ }^{2}$ \\ ${ }^{1}$ Ural Federal University, Mira street, 19, 620002 Ekaterinburg, Russian Federation \\ ${ }^{2}$ De Montfort University, The Gateway, LE1 9BH, Leicester, United Kingdom
}

\begin{abstract}
This paper evaluates the legal status of the Russian federal government as a corporate governance participant using the example of large sectorial companies. The state commonly regulates economic processes and focuses on pursuing the public interest. It also acts as a guarantor of social responsibility, and this affects decision-making processes in state-owned corporations. In Russia, the federal government has always played an essential role in the business activities of enterprises. Many companies are known to be state-owned or have close links to the state authorities and policymakers. This raises an academic debate concerning the development of market competition, state participation, and business environment. We propose approaches to understanding the participation of the state and unitary enterprises in corporate governance in Russia. By employing secondary data analysis as well as examining the Russian legislation in corporate law, we attempt to determine the legal and social status of the federal government in managing large corporations. This study addresses the issues of the duality of the legal status of the government in corporate governance and its impact on managerial decision-making.
\end{abstract}

\section{Introduction}

The objectives of the government are to ensure the social and economic prosperity of the country. However, it does not only regulate civil and corporate relations but in some cases, also it is an equal party in business development [1]. Social justice can be achieved by generally establishing binding rules of conduct that strengthen market relations, which are the economic basis of Russia [2]. Legal entities of public law are shareholders of strategically and socially important companies. Hence, the improvement of corporate governance regulations is a continuous task that stems from the main characteristics of the current economic environment in Russia. All corporate governance participants (both private investors and state representatives) are interested in finding the ways to improve the company's performance, which predominately implies financial success as well as the attraction of additional external capital [3]. Some scholars suggest the need for reducing the

\footnotetext{
${ }^{*}$ Corresponding author: o.v.cherkasova@urfu.ru
} 
share of government participation in corporate legal relations and enhancing the legal regulation of federal property management [4]. The mechanism for expressing the will of the state regarding the state property management is complex, and its implementation is time-consuming, which negatively affects the joint-stock companies with state participation. This study aims to examine legal and social aspects of the government status in corporate governance, as well as state-business relations on the matters of corporate social responsibility (CSR). The objectives of this paper are to study various approaches to determining the legal and social status of the state in managing large corporations, conduct comparative and law enforcement analysis of state participation in corporate governance, analyse its social aspect, identify the challenges in the implementation of CSR for such corporations, and develop recommendations to address them.

\section{Materials and Methods}

In this paper, we used secondary sources to analyse state participation in managing large corporations in Russia. The Consultant Plus was used to discuss the legal aspect of this problem. The comparative legal method used in the paper involved comparing state-legal phenomena and processes and setting their similarities and differences [5]. We utilised the SPARK-Interfax database to examine the profiles of the companies explicitly focusing on the ownership structures with the help of the social network analysis approach [6]. This involved examination of the owners of the companies and their ownership share in other organisations as well as the general directors and their managerial roles and other types of connections and link in other enterprises. We strived to establish the quality of state legal systems, including certain institutions and norms. The mixed method of comparative legal approach and social network analysis also enabled examining the legal and social status of the state as a participant in large businesses concerning foreign public orders.

\section{Results and Discussion}

\subsection{Theoretical debate}

In Russia, joint-stock companies have become prevalent since the extensive privatisation of state property in the 1990s after the collapse of the Soviet Union. This resulted in implementation of significant number of contradictory laws regulating management of joint-stock companies including those with state participation [7]. Sukhanov states that the peculiarities of the legal status of any state are determined by its political authority and national sovereignty, which allows it to regulate various relations (including property relations) and establish generally binding rules of conduct for all participants, as well as the procedure for litigation for possible disputes [8]. Orlov indicates the socially significant principles in the legal personality of legal entities of public law as participants in private law relations. He also suggests that these entities are created in public interests [9].

Some scholars describe people who represent the interests of legal entities of public law differently. Rasmussen et al. (2014) suggest the term "representatives of public interests"; this people may be civil servants [10]. The following terms are also proposed: "representatives of the interests of the Russian Federation", "professional attorneys" and "independent directors" [11]. Makarova believes that the powers of a professional attorney should be provided for in a contract [12]. Under conditions described in the contract, an attorney should be prudent and sincere in implementation of his duties and exercising his powers attributed to competence of the board of directors. The question is whether it is possible to bring to responsibility a member of the board of directors who is a 
representative of public interests. In essence, the member does not express his own will when voting, but fulfills instructions given to him.

The peculiarity of corporate relations involving legal entities of public law is manifested in the set of their rights with regard to participation in the company management (a golden share) [13]. A golden share is not a specific issuance security, but a conventional name for corporate right, which can arise only in a legal entity of public law that is a shareholder of an open joint-stock company. A golden share gives a veto when deciding on certain issues by the general meeting of shareholders, but not by the board of directors. In the latter case a representative of a legal entity of public law enjoys equal participation with other members of the board. However, it seems that the rights granted to legal entities of public law are not always effective for corporate governance, since it allows the state, its constituent units and municipalities to intervene in business decision-making, which has a negative impact on the potential investors' motivation.

\subsection{The legal aspect of state participation in corporate governance}

Models of legal regulation of state-owned companies vary across countries. The system of competent bodies and state authorities are mandated to act in civil law transactions on behalf of the government in different countries depending on the territorial administrative structure and the current governance model [14]. The legislators of the United States and Great Britain, being aware of the term "legal person", have so far rejected to use the notion "legal entity under public law". The latter appeared only in the late 1990s, as a response to the integration processes. Traditionally, in English and US law, the notion of government, local or public authority is used instead of this concept $[15,16]$. The corporate governance in countries where the government is an active and professional owner is very much in line with the OECD Guidelines on Corporate Governance of State-Owned Enterprises of 2005 [17]. This document supplements the OECD Principles of Corporate Governance developed in 1999. The Principles are non-binding and do not give detailed instructions for national legislation, but cover the essential aspects of corporate governance. These include the rights of shareholders, equal treatment of them, the shareholder's role in the company's share capital, information disclosure and transparency, as well as the responsibilities of the board of directors. According to Wang and Sarkis, the government support of corporations is essential for social entrepreneurship. They note that the company's social responsibility influences corporate governance while creating joint innovations in developing countries [18].

Table 1. Russian corporations with state participation

\begin{tabular}{|c|c|c|}
\hline $\begin{array}{c}\text { Companies with state share } \\
\text { less than 50 \% }\end{array}$ & $\begin{array}{c}\text { Companies with state share } \\
\text { between 50\% and 75\% }\end{array}$ & $\begin{array}{c}\text { Companies with state share } \\
\text { more than 75\% }\end{array}$ \\
\hline Tatneft & Kamaz & Sberbank \\
\hline Moscow Exchange & VTB Bank & Rosseti \\
\hline VSMPO - AVISMA & Aeroflot & RusHydro \\
\hline United Wagon Company & Rostelecom & Lenenergo \\
\hline Inter RAO UES & Federal Grid Company & United Aircraft Corporation \\
\hline $\begin{array}{c}\text { Territorial Generating } \\
\text { Company № 1 } \\
\text { (TGC-1) }\end{array}$ & Rosneft & Transneft \\
\hline $\begin{array}{c}\text { Second Generating Company } \\
\text { (OGC-2) }\end{array}$ & IDGC Volga & Irkut Corporation \\
\hline $\begin{array}{c}\text { Gazprom Neft } \\
\text { IDGC North-West }\end{array}$ & $\begin{array}{c}\text { Interregional Distribution } \\
\text { Grid Company of the South }\end{array}$ & $\begin{array}{c}\text { Novorossiysk Commercial } \\
\text { Sea Port }\end{array}$ \\
\hline & Bashneft & Rosseti Northern Caucasus \\
\hline
\end{tabular}


Table 1. Continued

\begin{tabular}{|c|c|c|}
\hline $\begin{array}{c}\text { IDGC Central and Volga } \\
\text { Regions }\end{array}$ & IDGC Siberia & Kubanenergo \\
\hline IDGC Urals & Gazprom & \\
\hline Rosseti Centre & ALROSA & \\
\hline & ALROSA-Nurba & \\
\hline & Mosenergo & \\
\hline & $\begin{array}{c}\text { Moscow United Electric } \\
\text { Grid Company }\end{array}$ & \\
\hline
\end{tabular}

Some circumstances should be taken into consideration in analysing the civil status of a legal entity of public law under Russian law. First, it is the integrated nature of the legal regulation of the relations in question as the federal government is the largest shareholder in the Russian market. The share of state-owned companies that disclose their shareholder structure in the Moscow Exchange Index is at least $45 \%$. In many largest and most liquid assets, the government owns a significant share (tab. 1). Under article 125 of the Civil Code of the Russian Federation, legal entities of public law exercise their rights and obligations through state and local governments, acting on their behalf. As state and local authorities combine the functions of a shareholder and an authorised representative, they are concerned with developing strategic industries, promoting social interests, ensuring political and economic security, the stability of property transactions and safety of state and municipal property. The above shows the duality of the legal status of the Russian Federation in corporate governance.

\subsection{The social aspect of state participation in corporate governance}

An understanding of the social function of entrepreneurship creates favourable conditions for harmonizing public-private interest, as well as for shifting responsibilities when solving social problems. Corporate social responsibility being of high relevance, it is essential to build morale and ethical model of the behaviour of the Russian Federation in business management [19]. According to Wan and Chen, corporate culture increases the social value of an organization, which has a strong positive impact on the efficiency of corporate social responsibility [20]. According to the Chinese doctrine, "focusing only on shareholders' financial return is not consistent with the concept of sustainable corporate governance". Corporate social responsibility is a non-financial performance index [21]. Political corporate social responsibility theory implies an extensive interpretation of politics and corporations, including impacts that may range from voluntary initiatives to overcome governance gaps to avoiding state regulation via corporate political activity [22]. Celik states that good corporate governance is not a goal in itself. For balancing interests of developing companies' shareholders, it is especially important to have access to equity capital [23]. For instance, to support the sustainable development of agribusiness, corporations can deploy 'power of presence' to influence national policy development and sustainability in regional and local practices. Investment and trade policies currently foster agribusiness but overlook environmental assessments that expose social and ecological contradictions, such as on competing water uses. State-donor relations enable smallholder integration in sugarcane as poverty reduction whilst agribusinesses are limiting their participation through controls on resources and production systems" [24]. Also, organizations are developing corporate social responsibility strategies to promote ethical leadership among human resource managers. Such measures offer real ways to ensure business sustainability in a dynamic environment. An ethical leader sets ethical standard for 
morality, honesty, reliability and effectively balances the interests of stakeholders. This makes the company's social responsibility strategy results-based and long-term [25].

CSR in Russia is developing quite rapidly because it is possible to draw on international experience in building this system. Nevertheless, international standards and approaches to the development of CSR are not easily accepted in Russian business. Therefore, CSR models in Russia have their own characteristics that are being embedded in the processes of global corporate development [26]. CSR initiatives mainly aim at ensuring compliance with certain official standards, as well as at creating a specific social image for the state. To a greater extent, the Russian government focuses on the formation of a legislative framework for socially responsible business. It is the government that is the main initiator of CSR, neither society nor business itself [27]. The Concept for Long-Term Socio-Economic Development of Russia Until 2020 expresses an intention to set up mechanisms strengthening business social responsibility and advancing corporate social reporting [28]. Both fundamental international principles and specific requirements for business in a particular country are taken into account in corporate management of CSR relations. There can be found the following examples of standard-setting documents applied to the business community:

- Corporate Code of Conduct [29] based on the principles of corporate governance developed by OECD;

- Social Charter of Russian Business (2004) [30], which establishes a set of fundamental principles of business practices;

- The standard of the Chamber of Commerce of the Russian Federation "Social Reporting of Enterprises and Organizations Registered in the Russian Federation"[31], which serves as a basis for the development of corporate management codes, and reiterates international principles of socially responsible business to a large extent.

The federal and regional governments are responsible for creating favourable conditions and regulatory frameworks for charity development and implementation without the state's direct intervention. The Federal Law "On Charitable Activities and Charitable Organizations" [32] lays the foundations of legal regulation of charitable activities, defines the possible forms of its support both by regional and federal governments to solve social problems by joint effort. For example, such companies as Lukoil and Gazprom are inspired by the concept of social responsibility and show their commitment to high international social standards and values of responsible business practices. They support federal and regional charitable projects and undertake charitable activities for target groups of the population in the regions of their business activities. Gazprom pays greater attention to sports events and promotes various international and Russian sports programs and initiatives. In 2001, "Lukoil" developed and approved the Social Code, defining key aspects of charitable and social activities. The Social Code determines two areas: social investments and traditional charitable assistance. Therefore, one of the key recommendations is the establishment of the norm on corporate social responsibility of the enterprise in statutes, ethical codes, mission statements, standards of socially responsible behaviour, business ethics programs, collective agreements, etc. This will foster the development of voluntary social entrepreneurship.

\section{Conclusions}

This paper examined legal and social aspects of the government status in corporate governance, as well as state-business relations on the matters of corporate social responsibility (CSR). Based on the conducted analysis, the following conclusions can be made. First, the government acts as a regulator of economic processes in society, as a 
guarantor of social responsibility of large business entities, and as an equal participant in civil transactions. This element affects managerial decision-making in large corporations with significant state participation. For this reason, both international and Russian scholars suggest the presence the dualism in the legal status of the Russian government concerning the management of large corporations. Second, the social status of a corporation with state participation also has specific characteristics. State-owned companies resolve social development problems using their own financial capacity both at the regional and federal levels. However, international standards and approaches to the development of CSR are not readily accepted by the Russian business. Therefore, CSR models in Russia have their own features which are being embedded in the processes of global corporate development. Thirdly, even though the Russian state focuses on the creation of the legislative framework for socially responsible business, the best solution would be to develop corporate social responsibility standards in local acts (internal documents) of the corporation.

\section{Acknowledgments}

The authors express special gratitude to the administration of School of Public Management and Entrepreneurship of the Ural Federal University named after the first Russian President Boris Yeltsin for the support and participation. The work was supported by Government Act 211 of the Russian Federation, contract № 02.A03.21.0006.

\section{References}

1. Q. Zhong, T. Tang, Emerging Markets Finance and Trade, 54(14), 3351 (2018)

2. O. V. Cherkasova, Conference proceeding $12^{\text {th }}$ International Days of Statistics and Economics, 640 (2018)

3. J. Zhai, Y. Wang, China Journal of Accounting Research, 9(4), 251 (2016)

4. A. Yakovlev, D. Ivanov, International Journal of Emerging Markets (2020)

5. O. Brand, Brooklyn Journal of International Law, 32, 405 (2006)

6. S. P. Borgatti, M. G. Everett, J. C. Johnson, Analyzing Social Networks, 2nd edition (2018)

7. J. S. Earle, S. Estrin, Economics of Planning, 36(1), 1 (2003)

8. E. A. Sukhanov, Journal of Russian Law, 1, 253 (2018)

9. V. Orlov, Introduction to Business Law in Russia (2013)

10. A. Rasmussen, B.J. Carroll, D. Lowery, European Journal of Political Research, 53(2), 250 (2014)

11. F. Heindler, Corporate and Unitary Legal Entities in Russia (2018)

12. O. Makarova, Civil Law, 4, 25 (2014)

13. A. Pezard, Brooklyn Journal of International Law, 21(1), 85 (1995)

14. G. Borisova, P. Brockman, J.M. Salas, A. Zagorchev, Journal of Banking \& Finance, 36(11), 2917 (2012)

15. E. Adegbite, P. Shrives, T. Nichol, Corporate Ownership \& Control, 9(1-2), 283 (2011)

16. C. Coglianese, E.K. Keating, M.L. Michael, T.J. Healey, NYUJL \& Bus, 1(1), 219 (2004)

17. OECD Guidelines on Corporate Governance of State-Owned Enterprises are available, www.oecd.org/ 
18. Z. Wang, J. Sarkis, Journal of Cleaner Production, 162, 1607 (2017)

19. A. Kuznetsov, O. Kuznetsova, International Studies of Management \& Organization, 42(3), 35 (2012)

20. P. Wan, X. Chen, Y. Ke, Journal of Cleaner Production, 259, 120877 (2020)

21. S. Schultz, P. Seele, Business Ethics: A European Review, 29(2), 303 (2020)

22. Y. Song, H. Wang, M. Zhu, Financial Innovation, 4(2), 1 (2018)

23. F. Çelik, Procedia Computer Science, 158, 191 (2019)

24. S. Manda, A. Tallontire, A.J. Dougill, The Journal of Development Studies, 56(1), 186 (2020)

25. R. Lombardi, S. Manfredi, B. Cuozzo, M. Palmaccio, Corporate Social Responsibility and Environmental Management, 1 (2020)

26. J. Crotty, Business \& Society, 55(6), 825 (2014)

27. L.A. Henry, S. Nysten-Haarala, S. Tulaeva, M. Tysiachniouk, Europe-Asia Studies, 68(8), 1340 (2016)

28. The Resolution of the Government of Russia of November 17, 2008, № 1662-p «On the Concept for Long-Term Socio-Economic Development of Russia until 2020», Collection of Legislative Acts of the Russian Federation, November 24, 2008, № 47.

29. Letter of the Bank of Russia of April 12, 2014, № 06-52/2463 “On the Corporate Code of Conduct", Gazette of the Bank of Russia, 40 (2014)

30. The Social Charter of Russian Business adopted by the RUIE Assembly in November 16 (2004)

31. The Resolution of the Board of the Chamber of Commerce and Industry of the Russian Federation of June 16, 2005, № 114-10 "On the development of expert and evaluation activities, certification of goods and services in the system of chambers of commerce in the Russian Federation", http://www.consultant.ru/

32. The Federal Law "On Charitable Activities and Charitable Organizations", http://www.consultant.ru/ 